\title{
Karen youth transitions at the Thai-Myanmar border ${ }^{1}$
}

\section{Introduction and background}

This article explores how the context of forced migration at the Thai-Myanmar border affects youth transitions amongst the displaced Karen people. Youth transitions to adulthood are framed by political, social, cultural, and economic contexts that open or close access to services and opportunities in the field of health, education and jobs. Accordingly, depending on the location where young people grow up, they face different challenges as they make their transition to adulthood (Hardgrove et al. 2014, 21-23).

This research examined youth transitions within a context of forced migration through the lenses of life course approaches and youth transition research. In general, life course approaches aim at understanding how individual biographies are structured over time by major social divisions such as gender, ethnicity and social status (Giddens and Sutton 2013, 346, Neale 2015, 26; Worth and Hardill 2015, 2). Accordingly, life course research is particularly sensitive to how individual agencies relate to social context and acknowledges that 'all life choices are contingent on the opportunities and constraints of social structure and culture' (Elder 1998, 2). Within life course research, transitions receive particular attention because they structure life trajectories and therefore help in understanding developmental changes. Early transitions are likely to impact on advantages and disadvantages in health, social participation, and wellbeing in later life (Elder 1998, 7; Kendig and Nazroo 2016, 6-7). The

\footnotetext{
${ }^{1}$ The author thanks Abby Hardgrove and two anonymous reviewers for commenting on previous versions of this article, Aranya Siriphon for her help with translations from Thai into English and her father, Franz Vogler, for the technical processing of the drawings. Finally, the author gratefully acknowledges a post-doctoral research scholarship received by the Oxford Institute of Population Ageing during the time she conducted this research.
} 
term 'transitions' has a variety of meanings and transition concepts are often used in differentiated and specific ways, for example, in terms of vertical and horizontal 'passages' (Kagan and Neuman 1998, 366). Vertical transitions may be thought of as key changes from one state or status to another, often associated with 'upward' shifts such as from primary to secondary school. This is important for youth transitions research that focuses on education. Yet, there are also less-formal changes in lives and routines that occur outside modern institutional settings and are rooted in local belief systems and expressed through rituals such as baptism, circumcision or marriage (Morrow 2003, 268). These social transitions are often referred to as 'rites of passage’, a term originally introduced by Van Gennep (1960). Horizontal transitions are less distinctive than vertical transitions and typically structure daily life. They refer to the movements men and women of different ages routinely make between various spheres of their lives (e.g., everyday movements between home and school).

In the 1990s, social research started to explore childhood and youth transitions in poor nonWestern countries (Reynolds 1991; Nieuwenhuys 1994; Punch 2002). Moreover, a range of social studies show that young people growing up in armed conflict and situations of displacement are resourceful in dealing with rupture and dissonance, even in extreme adversities such as war, internal displacement and flight to other countries (Boyden 2013; Boyden and de Berry 2004). In line with these findings, the present study assumes that young persons do not represent a homogeneous social group. Instead, the study argues that the social position of young people largely affects their childhood and youth transitions, incorporating the challenges they cope with during the process of growing up. Accordingly, the research employed a life course methodology that is sensitive to the impact of historical change and intersecting inequalities in individual youth biographies. The next section turns to research methods used in this study.

Research context, methods and ethics 


\section{Research context}

This study is based on ethnographic fieldwork with eighteen Karen youth aged 19 to 25 years who arrived in Thailand as displaced person from Myanmar. The Karen people in this study constitute one of the many ethnic nationalities in Myanmar and Thailand. However, rather than being a culturally homogenous group, there exists much diversity among the Karen, including religious identity and political affiliations. It is estimated that $50 \%$ of Karen in Myanmar say they are Buddhists, 30\% Christians and 20\% animists (Worland and Vaddhanaphuti 2013, 389). Previous military regimes deliberately exacerbated the religious divide among ethnic groups. As a result of these complex inter and intra-ethnic armed conflicts, thousands of ethnic minority people fled their homeland in Myanmar and crossed the border with Thailand in search of protection from fighting, food security and education. In December 2016, an estimated number of 102,607 persons were living in temporary shelters for displaced persons in Thailand, most of whom (79.4 \%) were ethnic Karen. (The Border Consortium 2017:6). Growing up in shelters for displaced persons affects children and youth's transitions to adulthood. Unlike their parents' generation they have access to primary and secondary education and thus often aspire to tertiary education and jobs outside the shelters. Education is delivered through different actors, most notably the Karen Education Department and a range of community based organizations. Young men and women who aspire for education beyond higher secondary school need to find support through humanitarian networks, including faith-based organizations. Among these, Buddhist and Christian religious institutions play key roles. (Horstmann 2011, 253; Jolliffe 2016ab). This research on Karen youth transitions, also drew on a faith-based organization, namely the Society of Jesuit (Jesuits) in the city of Chiang Mai, Thailand. During fieldwork in 2013, the author learned that Jesuit priests had established a small-scale education project for displaced Karen youth from Myanmar. They named the school after Father Pedro Arrupe, the founder 
of the Jesuit Refugee Service. Their project started by bringing Karen youth from temporary shelters to a Thai Karen village in the highlands of Chiang Mai province, Thailand. When the author visited the education project in December 2013, the students seemed integrated into village life, participating in the communal learning and working processes. Accordingly, the author started with participant observation and informal interviews in November 2013, followed by participatory research exercises in December 2013.

\section{Research methods}

This study used participatory research methods in combination with participant observation, semi-structured interviews and essay writing. Participatory research tools are used within youth studies, especially when it comes to understanding the lives of children growing up in poverty, war and conflict zones and different displacement sites (Akesson 2015; Boyden and Ennew 1997; Evans 2013; Hart and Tyre 2006).

For participatory research exercises, the author worked with the research assistance of students from Chiang Mai University whom the author previously trained in participatory research methods. The presence of a translator was important for communication with research assistants and research participants whose mother tongues were Thai and Karen. We thus explained to research participants what participatory research methods were about and asked for their oral consent to participate in the research. We distributed white paper sheets and colour pencils and allowed students a full hour to draw their life courses. After a lunch break we resumed our work in the classroom. We encouraged students to present their life course drawings to their peers. Listening to students' narrations of their life course was a profound experience. During data analysis schooling and education emerged as central themes in the displaced students` life course drawings. Moreover, the transition from their conflict affected home villages to temporary shelters in Thailand appeared as an important transition point. 
Therefore, when revisiting the group in March 2015, the Karen youth were encouraged to each write an essay about the role of school in their lives and another essay about their home villages. These 27 essays were helpful to better understand individual trajectories. In addition, it was possible to obtain the Jesuits' permission to read 25 essays the young people wrote during an English language camp in June and July 2014.

\section{Research ethics}

Ethical issues have been treated thoughtfully throughout the whole research process of fieldwork preparation, data gathering, analysis and representation of research findings. Due to the research procedure, the application for ethical review was submitted after the research project started. The University of Oxford's Social Sciences and Humanities Inter-Divisional Research Ethics Committee (IDREC) thus conducted an audit review of the ethical issues and judged the research as meeting appropriate ethical standards.

Throughout the research, the author negotiated and renegotiated informed consent orally and made every effort to ensure confidentiality. Before actively engaging individuals in the research process, their consent was always established and the author clarified the purpose of the research and the data use. Research participants' informed consent and confidentiality were maintained to the best of the author's knowledge and ability throughout the research process. We also paid close attention to other ethical issues pertaining to the research with vulnerable and displaced populations, such as protecting research participants and honouring trust, avoiding undue intrusion, negotiating informed consent, rights to confidentiality and anonymity, as well as individual responsibilities for maintaining professional and scholarly integrity (British Sociological Association, 2002; Refugee Studies Centre 2007; Saunders, Kitzinger and Kitzinger 2015). The following section discusses the research results.

\section{Results}


All participants to this study were born in Myanmar during the early 1990s. Accordingly, they all spent their early and middle childhood in unstable war zones and experienced early disadvantages. Visual data produced during participatory research exercises illustrates the complexities of growing up in Myanmar and how external socio-political events impact on individual life courses. The following case study is a good example of how a 23-year-old Karen man saw his life course marked by conflict and displacement.

Figure 1 Saw Loo Shwe's life course drawing (retouched)

Saw Loo Shwe ${ }^{2}$ was born in 1990. At the age of seven, he started primary school in his village. The learning was frequently interrupted because Burmese soldiers attacked the village. Eventually, in 1998 Burmese soldiers burned the village. After this incident, Saw Loo Shew and his family fled into the deep jungle. Saw Loo Shew marked this turning point in his life course at the left-hand side of his drawing. During their flight into the jungle, Saw Loo Shew lost two of his siblings in one week. He refers to this event writing in broken English³: “my family fulfil of broken heart because my brother and sister fly to heaven at the same time.” When his family ran out of rice they decided to cross the border with Thailand to find protection in one of the shelters for displaced persons. After one month, they moved on to another shelter where Saw Loo Shew eventually graduated from high school. As depicted in the middle of the right-hand side of the drawing, Saw Loo Shew aspired for a political career as a future Karen president. Therefore, he was keen to study at university. As a first stepping stone towards this

\footnotetext{
${ }^{2}$ Displaced youth's names are pseudonyms

${ }^{3}$ Direct quotations from Karen youth's drawings and essays are kept in the original, often broken English.
} 
goal, he enrolled in the Jesuit education programme mentioned above. With a group of other Karen youth, he thus left the temporary shelter in 2013 and moved to a Thai Karen village in the highlands of Chiang Mai province. There he spent two years and two months studying Thai and English as well as assisting the villagers with communal agricultural work, such as transplanting and harvesting rice. This important time of transition from the border shelter into Thai society is marked in the upper right hand part of the drawing. For his adult life, Saw Loo Shew envisaged returning to Myanmar where he hoped to marry and care for his ageing parents. His occupational aspiration was to help the poor of his country in the role of a Karen president.

Like Saw Loo Shwe's case study, other research participants expressed in their drawings how their early childhood and youth had been marked by the constraints of extreme poverty in war affected communities of Eastern Myanmar. The early disadvantages they experienced relate particularly to starting formal education later than children in politically stable settings. While some of the Karen women and men from Myanmar started school at around the age of six years, one young man reported that he was ten years old before he started studying and that he had spent the years before helping his household by caring for a buffalo. Also, another male research participant was already 12 years old when he started to attend school.

Lack of resources also caused early disadvantages. All research participants mentioned that the schools they attended lacked learning material and stationary. They also complained about frequent absence of teachers as well as the interruption of learning due to armed conflict in their area. Formal learning was sometimes also interrupted for students to help their teacher with the rice harvest or other agricultural tasks. These are routine activities that usually involve the whole community in Karen villages on both sides of the Thai-Myanmar border. Once the seasonal work had been completed everyone, including the children and young people, resumed the activities they had suspended for the duration of collective agricultural work. In contrast to these routine activities, the interruption of learning due to armed clashes is what the 
Karen youth complained about in their drawings. These clashes typically caused children and their families to flee unexpectedly into the jungle: "Sometimes I was not free to study because the Burmese attacked my village. Therefore, we had to move to the jungle because if we did not move to the jungle they would have killed us. Sometimes I had problems with studying and I went into the jungle because I was afraid of Burmese soldiers” (Essay, March 2015). Although this essay only mentions aggression from Burmese soldiers, the Democratic Karen Buddhist Army (DKBA) have collaborated with the Burmese soldiers since 1994. It is therefore likely that armed clashes also involved intra-ethnic violence between Karen from different armed groups.

Research results also suggest that the inability to study may cause low levels of self-esteem among young adults. For instance, one research participant emphasized how he felt ashamed for his lack of knowledge and "bad" in his life. He started to feel better when his carers encouraged him to study in a temporary shelter in Thailand:

"When I was a child I was not free to study [because there were attacks by the Burmese army and because of lack of material]. Now I have a problem about speaking in other languages. Therefore, I feel bad in my life. After studying in Karen state, I came to Thailand where I received more education and had more time to study. So, I felt very good. But when I was a child, my basis was not so good, so now I have many problems with studying. However, I will try the best with my studying because people who take care of me encourage me. So, I will try my best in my studies and in my life” (Essay, March 2015).

So, migration to shelters for displaced people in Thailand was for many Karen youth a feasible way out of a life of internal displacement and limited education opportunities due to the prolonged armed conflict in Myanmar. 
Life in shelters for displaced persons: education and aspirations

For those youth who crossed the border to shelters for displaced people in Thailand, a range of secular and faith-based organizations provide education, including nursery, primary, secondary and post-secondary education as well as vocational training and adult learning (Oh, 2010). The following case study illustrates a young woman’s migration for education:

Thida was born into a family of seven children in Taungoo, a district level city in the Bago region of Myanmar. At the age of five she started school in her village. She remembered with fondness the time in the village school built of bamboo and leaves. The medium of instruction was her Karen mother tongue and teachers were generally kind to students. A few years later (she did not say how many years), she had to leave her village because of ongoing fighting. Next, she made the transition to a high school. This school was much bigger than her village school and built with cement. The medium of instruction was Burmese and therefore Thida had difficulties following the teaching. In her essay Thida emphasised how hard her parents worked to pay for her education. When she graduated from high school she was keen to continue her education, but her parents did not have the means to support post-secondary education. Thus, Thida decided to leave Myanmar and go to Thailand where she knew that post-secondary education was being made available inside the shelters for displaced persons. When she reached Thailand, she was offered a place at the Karen Adventist Academy, a school that offered primary and secondary education for over 1000 students in one of the shelters. The teaching was free and included a dormitory place. The curriculum included eight subjects: Bible Studies, Karen Language, English Language, History, Geography, Hygiene, Commerce and Theory of Education. Thida studied at this school for two years and graduated in 2011.

Thida's case study highlights how the transition into a shelter for displaced persons signifies a major turning point for boys and girls who grew up in poverty stricken rural Myanmar where 
education was poorly provided. Of course, access to regular secondary education also impacts on young peoples' life course aspirations. In contrast to their parents' and grandparents' generation they are less keen on becoming agricultural producers. Rather, the youth in this study aspired for professional careers as teachers, translators, nurses and medical doctors. These changing aspirations are also related to the fact that most displaced Karen youth have passed their childhood and teenage years in areas where farming was not allowed. In Myanmar, they experienced how soldiers purposefully damaged their family's crops. Consequently, they have lost access to land. So, there is no family land to inherit from one generation to another. In addition, youth who spent many years in shelters for displaced people lack practical knowledge of farming. Instead of growing their own crops, for years they received rice and beans through a consortium of international NGOs on the Thai-Myanmar border. NGO workers only recently started to introduce livelihood programmes that focused on weaving, chicken and pig raising, community gardens, kitchen gardens and livestock raising as well as training in seasonal rice production. However, research suggests that this strategy only seemed to be successful for adults who are still connected with the places and locations they fled from in Myanmar. By contrast, youth often have no knowledge or interest in farming. (Keereepaibool 2016, 45).

The political changes in Myanmar also impact on youth aspirations. A recent spot check conducted in March 2016 among Karen camp resident teacher trainers in two temporary shelters, found that many Karen would prefer to stay in the shelters rather than to return to Myanmar where housing, food or job opportunities are insecure. In this context, the job aspirations of Karen youth included working for NGOs who operate inside Myanmar, working for businesses that use English as a lingua franca, or working in education, which in Myanmar is frequently delivered in English (Jolliffe 2016b, 122). Others aspired to continue their education at English or Thai speaking colleges or universities. Yet, to access tertiary education, 
displaced youth had to pass standardized recognized tests for which thorough preparation is necessary. In 2016, a full range of humanitarian organizations offered study programmes in preparation for transition to higher education or the job markets. Often, these programmes were run in rural and urban areas outside the shelters.

\section{Life in Thai society: integration and marginalization}

Youth who participated in this study shared the experience of moving out of the temporary shelters into wider Thai society. The reason for this transition was their aspiration for postsecondary education offered by the Jesuits through the small-scale Arrupe education project. As mentioned above, the project was established in 2013 and located for the first two years in a Thai Karen village in the highlands of northern Thailand. Because one of the Jesuit priests was himself of Karen origin, he understood that the Karen youth's transition from the border shelters into wider Thai society could be assisted by allowing them to live for a while in a village with Thai Karen people, i.e. Karen people who were born and raised in Thailand and who held Thai citizenship. So, from the beginning of this education project's, the Karen in the Thai Karen village encouraged the local integration of displaced Karen youth by teaching them the Thai language. In addition to language learning, displaced youth from Myanmar participated in the seasonal agricultural activities of their Thai Karen host community. During the rainy season in May they assisted local families to work on their rice paddies. Having grown up in temporary shelters where rice had been provided by humanitarian aid agencies, working on the rice fields in the village was for most of them a new experience and a key step towards Karen cultural ideas about adulthood and self-sufficiency. In addition to these daily and seasonal working activities international volunteers visited the displaced youth and provided regular teaching in the English language. This educational training and exposure to local and international teachers, in turn, encouraged them to develop professional occupational aspirations. 
Figure 2 Thida's life course drawing (details) showing the Jesuits' "Arrupe School” as a stepping stone towards university education and work as a medical doctor

Thida's drawing (Figure 2) highlights the importance of the Jesuits' “Arrupe School”. After completing high school at the Karen Adventist Academy in the shelter for displaced persons, she applied to the Jesuits' post-secondary education programme which in her drawing appears as a stepping stone towards university studies and a professional career as medical doctor.

In 2015, the education project was transferred from the Thai Karen village in the highlands to the Jesuit retreat centre in the city of Chiang Mai. This transition was marked by associated changes including changes in settings (from rural to urban), dominant language (from Karen to Thai), status, roles and relationships. Indeed, moving from a rural to an urban setting involved major cultural changes. In the village displaced Karen youth shared their Karen mother tongue with the Thai Karen villagers. Although the Karen youth from Myanmar differed from the Thai Karen in terms of citizenship status, social status, education and practical knowledge about farming, sharing the same mother tongue allowed for mutual trust building and the displaced youths' integration into the village. By contrast, in the city of Chiang Mai, they had to use the majority Thai language which they felt they had not yet mastered sufficiently. This linguistic disadvantage, coupled with their lack of Thai citizenship status, caused fear of social exclusion especially when facing Thai authorities such as the police. As one research participant put it:” When I saw the policemen in Chiang Mai, I felt so much fear because I am not a Thai citizen. So, if the policemen catch me, it is not easy for me. Furthermore, I cannot speak Thai neither” (Essays, June 2014). 
The Jesuits were aware of structural constraints based on students' ethnicity and citizenship status. They realized that only a few of their students would go to university. Therefore, the curriculum at the education project in the city of Chiang Mai continued to include vocational training in practical life skills which would be useful in the job market. The Jesuits also helped the eighteen displaced Karen students to conduct internships and find job opportunities. In this way, the young men and women were free to discern in which direction they would like their adult lives to develop. Indeed, seven students - three women and four men - left the programme for varied reasons: Thida and Saw Loo Shwe, who were mentioned earlier in this article, as well as another female research participant, went to Bangkok to receive a month's long training to prepare them for administrative work in a factory in Yangon. According to Tara Milutis, a US filmmaker, it seemed they had been convinced by someone in Chiang Mai that they were too old to achieve the professional careers they aspired to with their studies. So, they decided to make the transition to work. (Milutis, email correspondence, 9 and 10 July 2016) Also another male research participant found work in Bangkok. One woman returned to her native village in Kayin State of Myanmar to help her parental household. One young man was called back to the shelter for displaced persons by his parents as they wanted to apply together as a family for resettlement in a third country. Two other young men left the Arrupe school and returned to the shelter for displaced persons for marriage. The remaining nine students continued in the education project run in the city of Chiang Mai. In this way, the small-scale Jesuit education project encouraged aspirations whilst being realistic about the opportunities and constraints displaced Karen youth from Myanmar experience in Thai society.

Social relationships and networks 
Social relationships and networks structure young peoples' transition experiences. Results of this study suggest that among the displaced Karen youth from Myanmar, aspirations for higher education were often related to their parents' aspirations. Indeed, although they largely grew up in war zones and temporary shelters for displaced persons, research participants emphasised how much their parents encouraged their studies in the hope education may help their children to lead different lives from their life as farmers. In this respect, one research participant notes: “My parents (...) don’t want me to do like them because they love me so much” (Essay, July 2014). Others also emphasise their parents' support of their studies: My parents are very good people (...) They try to work hard for their children to have a good place and to have enough food. They sent their children to school to get education and to become a scholar” (Essay, July 2014).

Teachers also have a vital role in the lives of displaced youth. One female research participants wrote in her essay: “Teachers are like parents” (Essay, July 2014) thus reflecting a particularly Buddhist value and respect for teachers (Buadaeng 2003, 208). Importantly, teachers can also have a dominant role. While some research participants understood, their teachers were caring for them like their own parents, others said they felt fear when their teachers scolded and punished them. One research participant, for instance, mentioned escaping from the school dormitory because of fear of the school caretakers (Essay, June 2014)

Within a context of displacement, social relations and networks between households, schools and other, often faith-based, institutions are significant ways out of poverty. Research participants' essays illustrate the importance of parental support in encouraging educational aspirations, of supportive networks to access education and of friends to help them navigate the educational system. Conversely, left to themselves, research participants felt they encountered a myriad of problems. For instance, one young man recalls in an essay his arrival in a shelter for displaced persons in Thailand: 
"When I was living in the camp, I had to face some problems that were very difficult. Because, my family was not with me, I had to take care of everything by myself. Sometimes I had to face serious diseases. I also faced the problem that I didn't have money to buy a candle for reading books. But I didn't feel weak because God was with me and tested my life to have many experiences during my studies.” (Essay, July 2014)

Social relationships with family members often persisted despite migration and long periods of not seeing each other. With the help of the Jesuits some youth in this study visited their home villages in rural Myanmar. They described their home visits in essays emphasizing the importance of attending events that marked life course transitions such as the marriage of their relatives or seasonal festivities like the Karen Revolution Day on $31^{\text {st }}$ January. They also described working with their families and communities on shared communal tasks, such as hunting and fishing, as well as collecting vegetables and leaves for thatching roofs (Essays, March 2015)

Thus, for the research participants, religious networks such as the Jesuits in the city of Chiang Mai, became significant in facilitating not only access to education but also safe movements between locations in Thailand and Myanmar. Importantly, the network of the Jesuit Order was also open to Buddhist youth. This is illustrated in Figure 3:

Figure 3 Saw Mor Sow's life course showing the rite of passage of his ordination as a Buddhist novice $n$ the shelter for displaced people and his intention to life according to Buddhist precepts in his old age

Saw Mor Sow was born in Kayin State as the eldest child with five younger brothers. The family lived in a village located in a KNU warzone. They therefore left their home and in 2005 entered a temporary shelter for displaced persons in Thailand. From 2005 to 2012 Saw Mor Sow was enrolled in formal education in the shelter. At the time of drawing his life course, he was studying Thai for two years at the Jesuit education project in the Thai Karen village. He 
envisaged returning to the shelter for displaced persons to become a novice for nine days - an important cultural transition in Buddhism. After this, he planned to continue his studies at Chiang Mai University aiming for a professional career in education. Then he said he would be ready to care for his ageing parents, marry and work as a teacher. As a teacher, he would be particularly keen to develop mother tongue education. For his old age, Saw Mor Sow envisaged practicing the Buddhist virtues of no greed, anger and loss.

This example draws attention to the pivotal role of education in the lives of displaced Karen youth. Although Saw Mor Sow's childhood and adolescence were marked by war and displacement, education in the shelter for displaced persons in Thailand seemed to offer at least some structure and regularity. The importance of education is emphasized by Saw Mor Sow's aspiration to study at Chiang Mai University and to become a teacher himself. His drawing also highlights the role of social relationships and networks. Although separated from his family for the duration of his studies, he clearly envisaged caring for his family after graduation. Moreover, he envisaged himself returning the 'gift of education' (Jolliffe 2016a) to wider society by becoming a teacher himself. Saw Mor Sow's case study suggests that there need not be a contradiction between the private religious affiliation of individual youth and the institutional networks that facilitate their education. Finally, his coming and going between the shelter and the Jesuit education project illustrates the interlinkage between horizontal (e.g. moving between the temporary shelter at the border and Thai society) and vertical life course transitions (e.g. navigating the education system, becoming a Buddhist novice).

\section{Discussion}

This article builds upon and adds new insights to the literature on youth transitions in settings of armed conflict and displacement. My research findings highlight how structural inequalities 
and individual agency shape horizontal transitions between various locations and vertical transitions from one educational stage to another. The findings of this work suggest that it is ethnicity and citizenship status coupled with individual skills for networking with faith-based organizations that predominantly shape young Karen women's and men's pursuit for education within a context of forced migration. In other words, this research posits that in this particular research setting, ethnicity and citizenship status displace gender and age as primary markers of identity. This polarization of "ethnicity" shaped youth transitions at different locations within the continuum of displacement at the Thai-Myanmar border. In the Kayin State of Eastern Myanmar, the ethnic minority Karen children and youth had limited access to continuing formal education because of the long-term conflict between the former Burmese military regime and different armed ethnic groups. This deprivation of food and educational opportunities caused thousands of youth to leave their home country and cross the international border with Thailand to seek protection and education in shelters for displaced persons. In Thailand, their ethnic identity mattered for life within and outside the shelters. As mentioned in the introduction, the Karen constitute the "majority" group among the displaced people from Myanmar. Accordingly, educational programmes within shelters are often run in Karen (rather than another minority language) and this, in turn, makes active participation in formal education easier for Karen youth than for young people with different ethnic identities. At the same time, within the wider Thai society, the Karen are an ethnic “minority” group who over the last decades have mostly engaged in agricultural work in the highlands of northern Thailand. However, in recent years, Karen with Thai citizenship have increasingly accessed higher education and found professional work as teachers, bureaucrats and NGO workers. By contrast, the Karen from Myanmar in this study do not hold Thai citizenship. Therefore, they are doubly marginalized because of their ethnic “minority” status and their lack of citizenship. Moreover, the example of two women and one man who left the Jesuit education project for 
administrative work in a factory suggests that there exists an age bias towards young adults who keep on studying instead of earning their own living. Indeed, socio-economic interdependence within families and households also caused other research participants to stop studying in the city of Chiang Mai. Compared to these disadvantages, neither men nor women in this study mentioned gender as a cause of discrimination.

Findings of this work moreover highlight that the lives of Karen youth within a context of forced migration are structured according to horizontal and vertical transitions. Horizontal transitions are largely about the movement between geographical spaces such as migration from Kayin State in Myanmar to temporary shelters in Thailand. In Thailand, young people who participated in this study migrated onwards to villages and towns outside the parameters of the shelters. Sometimes, they returned to the shelters for major religious rites of passage such as becoming ordained as a Buddhist novice or marriage. Also, they occasionally crossed the border to return to Myanmar for brief family visits. These movements between geographical spaces were accompanied by changes in young men and women's activities, status, roles and relationships. Therefore, these horizontal transitions also shape vertical transitions.

Vertical transitions clearly centred on navigating formal education systems in rural Myanmar, in the temporary shelters for displaced persons and rural as well as urban post-secondary education projects in Thailand. This finding suggests that in a context of multiple displacement education can provide continuity and stability. Education may therefore enhance resilience of youth living in contexts of forced migration.

The study also highlighted the role of faith-based organisations in facilitating education. The research analysed the role of Jesuit priests in assisting Karen youth who aspire towards continuing their educational pathways beyond secondary school. Although an Order within the 
Roman Catholic Church, the Jesuits did not restrict admission to their programme to Roman Catholic or other Christian youth. As highlighted above, Buddhist youth participated in the Jesuits' education programme. Furthermore, the Jesuits' example of organizing visits to young peoples' home villages in Eastern Myanmar highlights the priests' respect for the young men and women's rural home cultures and family relationships. This in turn, suggests coherence rather than competition between family relationships and young peoples' involvement in this religious network. The training displaced Karen youth received at the Jesuit education programme encouraged them to develop professional aspirations. At the same time, intergenerational responsibilities vis-à-vis families and home communities may explain why some displaced youth feel the need to earn a cash income rather than pursuing their studies. This fact does not, however, render their studies meaningless. Although seven research participants interrupted their studies with the Jesuits this study suggests that small-scale projects can transform the lives of socio-politically marginalized youth, for example by equipping them with the linguistic and practical skills that allow them to successfully apply for jobs that provide an income for themselves and their families.

In terms of methodology, this study contributes to current scholarship on young people's life experiences in contexts of armed conflict and forced migration. Participatory research methods and essay writing proved fruitful methods to elucidate young peoples`own perspectives on their lives. Thus, rather than merely talking about them, these methods allowed the author to bring in the voices and points of view of the displaced youths. The drawing exercises were particularly suited to meet the methodological challenge of encouraging research participants to make explicit connections between external socio-political events and their individual life courses. The limitations of this work concern the small sample size. Whilst small sample sizes are very well suited for intersectional life course approaches, they do not lead to generalizable results. Moreover, the aspect of social desirability of answers is a fact that needs to be 
considered when evaluating the process of participatory research. In this study, research participants`declared aspirations were ambitious, mostly including university studies. This may be related to the presence of academics and student research assistants during participatory research exercises and Karen youth's conscious or unconscious efforts to please them with their answers. Despite these limitations, the combination of qualitative research methods suited this study and is recommended for future research in the area of youth transitions within a context of forced migration.

\section{References}

Akesson, Bre. 2015. “Using mapmaking to research the geographies of young children affected by political violence." In Researching the Lifecourse. Critical reflections from the social sciences, edited by Nancy Worth and Irene Hardill, 123-141. Bristol and Chicago: Policy Press.

Boyden, Jo. 2013.”'We're not going to suffer like this in the mud': educational aspirations, social mobility and independent child migration among populations living in poverty.“ Compare: A Journal of Comparative and International Education 43(5): 580-600.

Boyden, Jo, and Joanne de Berry, eds. 2004. Children and Youth on the Frontline. Ethnography, Armed Conflict and Displacement. New York: Berghahn.

Boyden, Jo, and Judith Ennew. 1997. Children in Focus: A Manual for Participatory Research with Children. Stockholm: Rädda Barnen. 
British Sociological Association. 2002. "Statement of Ethical Practice for the British Sociological Association.” $\quad$ Accessed $15 \quad$ November 2015. http://www.britsoc.co.uk/media/27107/StatementofEthicalPractice.pdf

Buadaeng, Kwanchewan. 2003. Buddhism, Christianity and the Ancestors: Religion and Pragmatism in a Skaw Karen Community of North Thailand. Chiang Mai: Social Research Institute, Chiang Mai University.

Elder, Glen. 1998. “The Life Course as Developmental Theory.” Child Development 69(1): 112.

Evans, Rosalind. 2013. "Towards a creative synthesis of participant observation and participatory research: Reflections on doing research with and on young Bhutanese refugees in Nepal.” Childhood 20(2): 169-184.

Giddens, Anthony, and Philip W. Sutton. 2013. Sociology. Cambridge: Polity Press.

Hardgrove, Abby, Kirrily Pells, Jo Boyden, and Paul Dornan.2014. Youth vulnerabilities in Life Course Transitions. New York: UNDP Human Development Report Office. 
Hart, Jason. 2008. Business as Usual? The Global Political Economy of Childhood Poverty, Young Lives Technical Note 13. Oxford: Young Lives.

Hart, Jason and Bex Tyrer. 2006. Research with children living in situations of armed conflict: concepts, ethics and methods, RSC Working Paper 30. Oxford: Refugee Studies Centre.

Horstmann, Alexander..2011. “Ethical Dilemmas and Identifications of Faith-Based Humanitarian Organizations in the Karen Refugee Crisis.” Journal of Refugee Studies 24(2): 513-532.

Jolliffe, Pia. 2016a. Learning, Migration and Intergenerational Relations. The Karen and the Gift of Education. London: Palgrave Macmillan.

.2016b. "Myanmar's Political Transition and Educational Aspirations of Refugees in Thailand.” NORRAG News 53: 122-123.

Kagan, Sharon L. and Michelle J. Neuman. 1998. "Lessons from three decades of transition research.” The Elementary School Journal 98(4): 365-379. 
Keereepaibool, Sutthida. 2016. Refugee repatriation on the move: Hopes and Fears from the voices of the returning refugees. Unpublished thesis, Bachelor of Arts in Social Science, Faculty of Social Science, Chiang Mai University.

Kendig, Hal and James Nazroo. 2016. "Life Course Influences on Inequalities in Later Life: Comparative Perspectives.” Journal of Population Ageing 9:1-7.

Morrow, Virginia. 2003. “Moving out of Childhood.”, In Childhood in Contexts, edited by Janet Maybin and Martin Woodhead, 267-301.Milton Keynes: Wiley and Sons, Open University.

Neale, Bren. 2015. "Time and the lifecourse: perspectives from qualitative longitudinal research” In Researching the Lifecourse. Critical reflections from the social sciences, edited by Nancy Worth and Irene Hardill, 25-41, Bristol and Chicago: Policy Press.

Nieuwenhuys, Olga.1994. Children's Lifeworlds: Gender, Welfare and Labour in the Developing World. London: Routledge.

Refugee Studies Centre. 2007. “Ethical Guidelines for Good Research Practice.” Refugee Survey Quarterly 26(3): 163-172. 
Reynolds, Pamela. 1991. Dance Civet Cat: Child Labour in the Zambezi Valley. Athens: University of Ohio Press.

Rogers, Benedict. 2012. Burma. A Nation at the Crossroads. London: Ryder.

Saunders, Benjamin, Jenny Kitzinger, and Celia Kitzinger. 2015. “Anonymising interview data: challenges and compromise in practice.“ Qualitative Research 15(5): 616 -632.

The Border Consortium. 2017. The Border Consortium Annual Report 2016. http://www.theborderconsortium.org/media/80489/2016-annual-report-jan-dec.pdf (accessed 4 April 2017)

United Nations. 2013. World Youth Report. Youth and Migration. New York: United Nations.

Van Gennep, Arnold. 1960. The Rites of Passage. Chicago: University of Chicago Press.

Vungsiriphisal, Premjai, Dares Chursri and Supang Chantavanich, eds. 2014. Humanitarian Assistance for Displaced Persons from Myanmar. Royal Thai Government Policy and Donor, INGO, NGO and UN Agency Delivery. Heidelberg: Springer. 
Willis, Paul E.2009. Learning to Labour: How Working Class Kids get Working Class Jobs. Farnham: Ashgate.

Worland, Shirley and Chayan Vaddhanaphuti. 2013. "Religious expressions of spirituality by displaced Karen from Burma: The need for a spiritually sensitive social work response.” International Social Work 56(3): 384-402.

Worth, Nancy and Irene Hardill, eds. 2015. Researching the Lifecourse. Critical reflections from the social sciences. Bristol and Chicago: Policy Press. 